\title{
Analisis Kepuasan Pelanggan Rawat Inap Puskesmas Berdasarkan Experiential Marketing
}

\author{
Muhammad Risya Rizki \\ STIKESYayasan Rumah Sakit Dr. Soetomo, Jl. Karangmenjangan 12 Surabaya 60286 \\ Surel:mrrizki49@gmail.com
}

\begin{abstract}
The objectives ofthisstudyis developingrecommendations to improve loyalty of inpatient customer ofCommunity health center in Pasrepan inPasuruanbased onexperiential marketingwhichconsistsofsense, feel, think, actandrelate. This wasa survey and observationalresearch. The samplein this study waspatients who weregoing homeafterthe process ofinpatient carein community health center in Pasrepan inPasuruan. The results showedthatthere wereseveralfactorsbased onthe analysisof thepatientexperience aboutsense, feel, think, andact,there wereseveralindicators ofaccessand service processesincommunity health center in Pasrepansthatprovided badexperienceto the patientsuch asparking lotshelter, walls painting, bathroom cleanlinessandcompleteness ofnon-medicalfacilities. Based on the analysis of sense, feel, think, andactlikely toaffect thepatientrelatein terms ofreutilizinginpatientcareandadvocacyto otherswhoneedin patient care. The conclusionofthis studyis that theconcept ofexperiential marketingwhichconsistsofsense, feel, think, actaffectedcustomerloyalty. Increasingcustomer loyaltycan be doneby improving thesense, feel, think, andact. This will improvepatientrelate, so thecustomerloyaltytowardsinpatient care of community health center inPasrepan in Pasuruan District.
\end{abstract}

\begin{abstract}
ABSTRAK
Tujuan dari penelitian ini adalah menyusun rekomendasi untuk meningkatkan loyalitas pelanggan rawat inap Puskesmas Pasrepan Kabupaten Pasuruan berdasarkan experiential marketing yang terdiri dari sense, feel, think, act dan relate.Penelitian ini adalah penelitian survei.sampel dalam penelitian ini adalah pasien yang akan pulang setelah menjalani proses rawat inap di Puskesmas Pasrepan Kabupaten Pasuruan. Hasil penelitian menunjukkan bahwa berdasarkan analisis pengalaman pasien terhadap sense, feel, think, dan act ada beberapa indikator akses dan proses pelayanan di Puskesmas Pasrepan yang memberikan pengalaman kurang baik kepada pasien diantaranya adalah keteduhan tempat parkir, cat dinding, kebersihan kamar mandi dan kelengkapan sarana non medis. Berdasarkan hasil analisis sense, feel, think, dan act cenderung berpengaruh terhadap relate pasien dalam hal memanfaatkan kembali layanan rawat inap dan melakukan advokasi kepada orang lain yang memerlukan layanan rawat inap. Meningkatkan loyalitas pelanggan dapat dilakukan dengan menyesuaikan sarana dan prasarana dengan standar yang ada dan dengan memperbaiki sense, feel, think, dan act pasien akan meningkatkan relate pasien terhadap rawat inap Puskesmas Pasrepan Kabupaten Pasuruan.
\end{abstract}

Keywords: Experiential marketing, loyalty, relate, inpatient public health center

Puskesmas adalah unit pelaksana teknis dinas kesehatan kabupaten atau kota yang bertanggung jawab menyelenggarakan pengembangan kesehatan di suatu wilayah kerja. Puskesmas bertanggungjawab menyelenggarakan pembangunan kesehatan di wilayah kerjanya yaitu meningkatkan kesadaran, kemauan, dan kemampuan hidup sehat bagi setiap orang yang bertempat tinggal di wilayah kerjanya agar terwujudnya derajat kesehatan yang setinggi-tingginya.

Instalasi rawat inap di Puskesmas merupakan upaya pengembangan yang diharapkan dapat meningkatkan akses 
masyarakat terhadap pelayanan kesehatan, serta keberadaan Puskesmas rawat inap sangat penting dalam mendekatkan layanan kesehatan pada masyarakat.

Kepuasan pasien dapat terjadi bila suatu keadaan dimana kebutuhan, keinginan dan harapan pasien dapat dipenuhi melalui produk atau jasa yang dikonsumsi.Oleh karena itu kepuasan pasien adalah rasio kualitas yang dirasakan oleh pasien dibagi dengan kebutuhan, keinginan, dan harapan pasien(Supriyanto, 2005).

Loyalitas dapat terbentuk apabila konsumen merasa puas dengan tingkat layanan yang diterima, dan berniat untuk melanjutkan hubungan. Salah satu konsep untuk membentuk loyalitas adalah melalui experiential marketing yaitu suatu konsep pemasaran yang bertujuan untuk membentuk pelanggan yang loyal dengan menyentuh emosi mereka dan membentuk suatu feeling positif terhadap suatu produk atau servis, experiential marketing terdiri dari lima unsur yaitu sense, feel, think, act, dan relate.

BOR (Bed occupancy Rate) adalah salah satu indikator penggunaan tempat tidur ruang rawat inap oleh masyarakat dengan nilai ideal 60\% - 85\% menurut Dinkes dengan asumsi TT > 100. BOR adalah salah satu indikator dari utilisasi ruang rawat inap, yang pada akhirnya bermuara pada kualitas pelayanan yang rendah akan berpengaruh pada loyalitas pasien, sehingga pasien akan pindah ke penyelenggara kesehatan yang lain dan pasien juga dapat menyebarkan image buruk provider pelayanan kesehatan tersebut kepada orang lain. Untuk berkembang puskesmas harus berupaya untuk meningkatkan kualitas pelayanannya kepada pasienya sehingga dapat menciptakan loyalitas pasien. Pasien yang loyal akan bisa meningkatkan daya jual dan laba Puskesmas tersebut.

Kabupaten pasuruan memiliki 33 Puskesmas dan 18 diantaranya adalah Puskesmas rawat inap. Beberapa Puskesmas rawat inap yang ada di Kabupaten Pasuruan menunjukan bahwa selama tiga tahun terakhir yaitu tahun 2009, tahun 2010, dan tahun 2011 BOR (Bed Occupancy Rate) berada di bawah standar nilai BOR ideal yaitu $10 \%$ dibawah nilai MOR.

.Puskesmas rawat inap non poned memiliki rata-rata nilai $B O R$ lebih rendah daripada rata-rata nilai BOR Puskesmas rawat inap poned. Data Puskesmas non poned di Kabupaten Pasuruan yang Memiliki Jumlah TT Rendah dan Rata-rata Nilai BOR Rendah Pada Tahun 2009, Tahun 2010, dan Tahun 2011 dapat dilihat pada tabel berikut

Tabel 1Data Puskesmas Non Poned di Kabupaten Pasuruan yang Memiliki Jumlah TT Rendah dan Rata-rata Nilai BOR Rendah Pada Tahun 2009, Tahun 2010, dan Tahun 2011

\begin{tabular}{clrrr}
\hline No & \multicolumn{1}{c}{ Puskesmas } & $\begin{array}{c}\text { Jumlah } \\
\text { TT }\end{array}$ & $\begin{array}{c}\text { MOR } \\
(\%)\end{array}$ & $\begin{array}{c}\text { Rata-rata } \\
\text { BOR }(\boldsymbol{\%})\end{array}$ \\
\hline 1 & Nongkojajar & 7 & 46,8 & 28,6 \\
2 & Tosari & 4 & 40,0 & 16,3 \\
3 & Pasrepan & 10 & 51,3 & 35,2 \\
4 & Prigen & 7 & 46,8 & 21,2 \\
5 & Sukorejo & 6 & 44,9 & 50,9 \\
6 & Bangil & 10 & 51,3 & 53,3 \\
7 & Winongan & 9 & 50,0 & 38,6 \\
8 & Rejoso & 8 & 48,5 & 50,8 \\
\hline Sumber & Laporan Profil & Dinas & Kesehatan Kabupaten Pasuruan \\
Tahun 2009 sampai 2011 & \multicolumn{4}{c}{}
\end{tabular}

Berdasarkan tabel 1 dapat diketahui bahwa ada 8 Puskesmas non poned di Kabupaten Pasuruan yang memiliki nilai BOR rendah dalam tiga tahun terakhir diantaranya adalah Puskesmas Nongkojajar, Tosari, Pasrepan, Prigen, Sukorejo, Bangil, Winongan dan rejoso. Untuk menentukan Puskesmas mana yang diteliti dilakukan pengundian pada Puskesmas yang memilki rata-rata nilai BOR rendah tetapi tidak terlalu rendah dan masih potensial untuk ditingkatkan yaitu Puskesmas Pasrepan dan Puskesmas Winongan, dan setelah dilakukan pengundian antara Puskesmas Pasrepan dan Puskesmas Winongan terpilihlah Puskesmas Pasrepan sebagai puskesmas yang diteliti.

Variabel yang diteliti dalam penelitian ini dibatasi hanya pada faktor konsumen dan pengalaman pasien rawat inap yang berhubungan dengan konsep experiential marketing.

Tujuan dari penelitian ini adalah menganalisis kepuasan pasien untuk 
meningkatkan loyalitas pelanggan rawat inap Puskesmas rawat inap Pasrepan Kabupaten Pasuruan berdasarkan experiential marketing.

\section{METODE}

Jenis dan rancang bangun penelitian ini adalah penelitian survei.Sifat penelitian ini adalah penelitian deskriptif yang menganalisis faktor-faktor yang mempengaruhi kepuasan pasien rawat inap di Puskesmas Pasrepan Kabupaten Pasuruan.Pengumpulan data dilakukan secara cross sectional.

Penelitian ini dilaksanakan di Puskesmas rawat inap Pasrepan Kabupaten Pasuruan. Penelitian ini dilaksanakan pada bulan Januari sampai Juli 2013.

Populasi dalam penelitian ini adalah pasien yang memanfaatkan ruang rawat inap di Puskesmas Kabupaten Pasuruan tahun 2013.Sampel dalam penelitian adalah pasien yang menjalani perawatan rawat inap di Puskesmas rawat inap pada Pertengahan Bulan Mei - Juni Tahun 2013.Besar sampel dalam penelitian ini adalah 35 orang pasien yang menjalani pelayanan rawat inap di Puskesmas rawat inap Pasrepan Kabupaten Pasuruan. Sampel diambil dengan cara accidental sampling karena sifat populasi dari pasien rawat inap yang terus bertumbuh atau berkembang serta pengambilan sampel dalam penelitian ini dibatasi dengan kriteria inklusi. Beberapa kriteria yang menjadi penilaian adalah sebagai berikut:

1. Pasien yang mau atau bersedia untuk diwawancarai dan atau bersedia mengisi kuesioner.

2. Pasien yang umurnya di bawah 18 tahun diwakili orang tua atau saudara yang menunggu pasien.

3. Pasien yang sudah lansia dan sulit berkomunikasi dapat diwakili oleh saudara yang menunggu pasien.

4. Pasien yang sudah atau yang akan mengakhiri proses pelayanan rawat inap di Puskesmas rawat inap Pasrepan Kabupaten Pasuruan.
Penelitian ini menggunakan kuesioner sebagai instrumen untuk mengumpulkan data primer.Kuesioner yang digunakan untuk mengumpulkan data pada setiap variabel dibuat dengan model pertanyaan tertutup.

Teknis analisis data dalam penelitian ini yaitu dilakukan proses pengolahan data dengan menganalisis pengalaman pasien terhadap akses dan proses pelayanan ruang rawat inap berdasarkan SEMs mulai dari sense, feel, think dan act. Selanjutnya setelah data dari hasil wawancara kuisioner ke pasien rawat inap dikumpulkan, dilakukan analisis data, yaitu:

1. Menganalisis pengalaman pasien ruang rawat inap berdasarkan SEMs mulai dari sense, feel, think dan act.

2. Menganalisis relate pasien terhadap ruang rawat inap Puskesmas Pasrepan Kabupaten Pasuruan.

3. Kemudian melihat adanya pengaruh pada sense, feel, think dan act terhadap relate pasien rawat inap Puskesmas Pasrepan Kabupaten Pasuruan dengan menggunakan crosstabulasi.

Isu strategis dapat ditentukan ditentukan dengan caramenggunakan konsep pareto $80 / 20$, yaitu menjadi masalah atau perlu diperbaiki bila penjumlahan rating 1 dan 2 sama dengan atau lebih dari $20 \%$ pada pengalaman responden berdasarkan sense, feel, think dan act.

Dari hasil isu strategis tersebut kemudian akan dilakukan FGD (Focus Group Discussion), sehingga akan menghasilkan rekomendasi upaya peningkatan loyalitas pelanggan rawat inap Puskesmas Pasrepan Kabupaten Pasuruan.

\section{HASIL DAN PEMBAHASAN}

\section{A. Karakteristik Konsumen Pengguna Ruang Rawat Inap}

Identifikasi karakteristik responden atau konsumen pengguna ruang rawat inap di puskesmas pada penelitian ini meliputi faktor konsumen yang terdiri dari umur, jenis kelamin, pekerjaan, tingkat ekonomi dan sumber pembiayaan. 


\section{Umur}

Usia atau umur dapat mempengaruhi pola permintaan pelayanan kesehatan. Semakin bertambahnya umur seseorang maka semakin besar pula kebutuhan akan pelayanan kesehatan. Berdasarkan hasil penelitian diketahui bahwa mayoritas umur responden kelompok umur 18 - 45 tahun yaitu kelompok umur yang masih produktif ada 13 responden $(37,1 \%)$ kemudian kelompok umur 46 - 60 tahun dan kelompok umur lebih dari 60 tahun ada 7 responden $(20,0 \%)$ sedangkan untuk kelompok umur kurang dari 17 tahun atau anak-anak ada 8 responden $(22.7 \%)$. Dari data diatas dapat kita lihat bahwa pengguna tebanyak dari kalangan kelompok umur yang masih produktif yang umumnya bertugas mencari nafkah untuk keluarga, dapat kita simpulkan bila pada kelompok umur tersebut banyak yang menjalani rawat inap maka akan berpengaruh pada keuangan keluarga.

\section{Jenis kelamin}

Jenis kelamin laki-laki menjadi jenis kelamin yang paling banyak dalam memanfaatkan fasilitas rawat inap di Puskesmas Pasrepan adalah 19 responden $(54,3 \%)$ dibandingkan jenis kelamin perempuan ada 16 responden $(45,7 \%)$.Berdasarkan hasil tersebut dapat disimpulkan jenis kelamin laki-laki paling dominan dalam memanfaatkan pelayanan kesehatan rawat inap di Puskesmas Pasrepan Kabupaten Pasuruan dapat dikarenakan lakilaki menjadi tulang punggung keluarga yang lebih banyak bekerja di luar rumah dari pada perempuan sehingga rentan terhadap penyakit.

\section{Pekerjaan}

Pekerjaan kepala keluarga responden yang menjalani rawat inap di Puskesmas Pasrepan mayoritas adalah sebagai petani ada 17 responden (48,6\%). Pekerjaan akan mempengaruhi pendapatan seseorang yang akan digunakan untuk memilih pelayanan kesehatan dan mayoritas responden adalah petani yang kebanyakan berpendidikan rendah dan berpendapatan rendah serta memiliki pengetahuan tentang kesehatan yang kurang sehingga petugas Puskesmas dalam memberikan layanan harus dapat memberikan informasi lebih dan sejelasjelasnya.

\section{Tingkat Ekonomi}

Mayoritas kelompok pendapatan keluarga dan kepala keluarga responden yang menjalani rawat inap di Puskesmas Pasrepan Kabupaten Pasuruan adalah kelompok responden denganpendapatan kurang dari Rp. 500.000 yang berjumlah 20 responden $(57,1 \%)$. Hal ini menunjukkan bahwa sebagian besar responden rawat inap di Puskesmas Pasrepan Kabupaten Pasuruan berasal dari keluarga ekonomi lemah, karena pendapatan keluarga dan kepala keluarga responden masih banyak yang dibawah UMR (upah minimum regional) Kabupaten Pasuruan sebesar Rp. 1.720.000,00.Pendapatan keluarga dapat dijadikan ukuran kesanggupan dari individu atau keluarga untuk memperoleh pelayanan kesehatan. Jika kebutuhan sehari-hari non kesehatan sulit untuk terpenuhi maka kebutuhan pelayanan kesehatan juga akan sulit untuk terpenuhi.

\section{Sumber Pembiayaan}

Sumber pembiayaan konsumen menunjukkan bahwa mayoritas responden menggunakan jamkesda atau jamkesmas ada 17 responden $(48,6 \%)$, lalu responden yang membayar dengan biaya sendiri ada 16 responden $(45,7 \%)$. Dari data tersebut menunjukkan bahwa mayoritas pengguna pelayanan rawat inap Puskesmas Pasrepan Kabupaten Pasuruan adalah keluarga dari ekonomi lemah karena mayoritas responden membayar dengan jamkesda atau jamkesmas dan Puskesmas Pasrepan Kabupaten Pasuruan adalah provider pelayanan kesehatan yang terdekat yang menerima cara pembayaran dengan menggunakan jamkesda atau jamkesmas. Hal ini menunjukkan bahwa sumber pembiyaan pasien akan menentukan kemana pasien akan memilih pelayanan kesehatan yang akan digunakan dan ini akan 
dapat berpengaruh terhadap kunjungan rawat inap puskesmas.

\section{B. Pengalaman Pasien Rawat Inap di Puskesmas Pasrepan Kabupaten Pasuruan berdasarkan sense, feel, think dan act}

Pengalaman pasien ruang rawat inap di Puskesmas Pasrepan Kabupaten Pasuruan diperoleh dengan menggunakan bantuan instrument kuesioner.

Menurut Kartajaya (2006) konsep eksperiential marketing yang terbagi lima tahapan yaitu sense, feel, think, act dan relate dapat membangun hubungan yang langgeng dengan pelanggan sehingga tercipta loyalitas pelanggan. Dan menurut penelitian Nehemia (2010) kelima variabel dalam experiential marketing yaitu sense, feel, think, act dan relate, memiliki pengaruh yang signifikan terhadap loyalitas pelanggan.

Sedangkan menurut Schmitt (1999) experiential marketing berfokus pada pengalaman pelanggan. Pengalaman yang terjadi sebagai akibat pertemuan, menjalani, atau melewati situasi tertentu.Pengalaman memberikan nilai-nilai indrawi, emosional, kognitif, perilaku dan relasional yang menggantikan nilai-nilai fungsional.

Experience pada dasarnya adalah sesuatu hal yang pribadi, yanghanya ada dalam pikiranindividu yang melibatkan emosional, fisik, intelektual, atau bahkan tingkat spiritual (Pine, Gilmore, 1998).pengalaman pasien dapat tercipta melalui sense, feel, think dan act terhadap variabel pada faktor Puskesmas.

Berdasarkan analisis hasil penelitian ada beberapa indikator yang memberikan pengalaman kurang baik kepada pasien yang menjalani proses rawat inap di Puskesmas Pasrepan Kabupaten Pasuruan.

Pengalaman yang diperoleh pasien selama menjalani rawat inap di Puskesmas Pasrepan terhadap akses dan proses pelayanan yang diberikan oleh pihak Puskesmas yang berdasarkan sense, feel, think dan actdapat dikategorikan menjadi kurang baik dan baik. Kategori pengalaman pasien ruang rawat inap di Puskesmas
Pasrepan Kabupaten Pasuruan dapat dilihat pada tabel di bawah ini.

Tabel 2. Kategori Pengalaman Pasien Ruang Rawat Inap di Puskesmas Pasrepan Kabupaten Pasuruan Berdasarkan Kuesioner Pertengahan Bulan Mei - Juni Tahun 2013

\begin{tabular}{|c|c|}
\hline Indikator & Kategori Pengalaman \\
\hline $\begin{array}{l}\text { Keteduhan tempat } \\
\text { parkir }\end{array}$ & $\begin{array}{lrr}\text { Kurang } & \text { baik pada } \\
\text { responden } & \text { kelompok } \\
\text { asuransi dan non asuransi }\end{array}$ \\
\hline Keterjangkauan tarif & $\begin{array}{l}\text { Kurang baik pada } \\
\text { responden kelompok non } \\
\text { asuransi }\end{array}$ \\
\hline $\begin{array}{l}\text { Sikap petugas } \\
\text { pendaftaran }\end{array}$ & Baik \\
\hline $\begin{array}{l}\text { Kecepatan alur } \\
\text { pelayanan }\end{array}$ & Baik \\
\hline Cat dinding & $\begin{array}{l}\text { Kurang baik pada } \\
\text { responden } \\
\text { asuransi dan non asuransi }\end{array}$ \\
\hline Kebersihan ruangan & $\begin{array}{lr}\text { Kurang } & \text { baik pada } \\
\text { responden } & \text { kelompok } \\
\text { asuransi } & \end{array}$ \\
\hline $\begin{array}{l}\text { Kebersihan kamar } \\
\text { mandi }\end{array}$ & $\begin{array}{l}\text { Kurang baik pada } \\
\text { responden } \\
\text { asuransi dan non asuransi }\end{array}$ \\
\hline $\begin{array}{l}\text { Kelengkapan sarana } \\
\text { medis }\end{array}$ & $\begin{array}{l}\text { Kurang baik pada } \\
\text { responden kelompok non } \\
\text { asuransi }\end{array}$ \\
\hline $\begin{array}{l}\text { Kelengkapan sarana } \\
\text { non medis }\end{array}$ & $\begin{array}{l}\text { Kurang baik pada } \\
\text { responden kelompok } \\
\text { asuransi dan non asuransi }\end{array}$ \\
\hline Makanan pasien & $\begin{array}{l}\text { Kurang baik pada think } \\
\text { responden kelompok non } \\
\text { asuransi }\end{array}$ \\
\hline Keterampilan dokter & Baik \\
\hline Sikap dokter & Baik \\
\hline Kesigapan dokter & Baik \\
\hline Keterampilan perawat & Baik \\
\hline Sikap perawat & Baik \\
\hline Kesigapan perawat & Baik \\
\hline Kecukupan tenaga & Baik \\
\hline Visite & Baik \\
\hline
\end{tabular}

Pada tabel 2 diatas diketahui indikator yang memberikan pengalaman yang baik kepada pasien akan menjadi keuntungan bagi Puskesmas karena pasien yang memiliki pengalaman yang baik terhadap pelayanan rawat inap Puskesmas Pasrepan akan dapat membangun hubungan yang langgeng dengan pelanggan sehingga tercipta loyalitas pelanggan. Indikator yang memiliki kategori 
pengalaman yang baik diantaranya adalah sikap petugas pendaftaran, kecepatan alur pelayanan, kebersihan ruanagan, keterampilan dokter, sikap dokter, keterampilan perawat, sikap perawat, dan kesigapan perawat. Sedangkan indikator yang memiliki pengalaman tidak baik dan menjadi masalah diantaranya adalah keteduhan tempat parkir, keterjangkauan tarif, cat dinding, kebersihan kamar mandi dan ruang perawatan, kesigapan dokter, makanan pasien, kecukupan tenaga, visite dan kelengkapan sarana medis dan non medis.

Indikatoryang memberikan pengalaman kurang baik kepada pasien antara lain adalah:

\section{Keteduhan tempat parkir}

Keteduhan tempat parkir menjadi isu strategis menurut pengalaman responden. Keadaan tempat parkir yang teduh akan mempengaruhi kenyamanan pelanggan dalam menaruh alat transportasinya pada saat pra pembelian karena tempat parkir berada pada akses pelayanan yang terletak di depan. Hal ini menurut Gaspersz (2011) kenyamanan dalam memperoleh pelayanan, berkaitan dengan lokasi, ruang tempat pelayanan, kemudahan menjangkau, tempat parkir kendaraan, ketersediaan informasi, petunjuk-petunjuk dan bentuk-bentuk lain dan menurut rini (2009) indera manusia dapat digunakan selama fase pengalaman (pra pembelian, pembelian dan sesudah pembelian) dalam mengkonsumsi sebuah produk atau jasa.

Puskesmas dapat membangun pengalaman yang baik kepada pelanggan dengan experiences providers dengan media menata spatial environtment yangdapat memberikan pengalaman baikyaitu dengan caramenata tempat parkir supaya lebih teratur dan rapi.

\section{Keterjangkauan tarif}

Keterjangkauan tarif menjadi isu strategis menurut pengalaman responden. Pasien pengguna pelayanan rawat inap di Puskesmas Pasrepan Kabupaten Pasuruan kebanyakan adalah dari golongan keluarga ekonomi kebawah, bagi mereka tarif rawat inap sebesar Rp 90.000 sehari dan jumlah hari perawatan yang bisa sampai lebih dari dua hari akan sangat memberatkan meraka. Dan banyak pasien miskin yang tidak memiliki kartu jamkesmas atau jamkesda, hal ini dapat di karenakan kurangnya pengetahuan pasien miskin tentang persyaratan jamkesda atau jamkesmas.Tarifpelayanan kesehatan termasuk tarif pelayanan rawat inap diatur dan ditentukan dengan peraturan daerah Kabupaten Pasuruan, tetapi pihak Puskesmas dapat menyampaikan informasi tentang jamkesmas melalui rapat lintas sektor seperti rakor kecamatan atau pada mini lokakarya.

Pengalaman kurang baik responden terhadap tarif pelayanan dapat ditutupi dengan meningkatkan hubungan antar manusia berkaitan dengan interaksi antara petugas kesehatan dan pasien, Petugas kesehatan diharapkan lebih melakukan sosialisasi persyaratan pasien miskin kepada pasien dan keluarganya.Menurut Brown (Wijono, 2007) salah satu dimensi mutu adalah akses terhadap pelayanan, dalam hal ini Akses berarti bahwa pelayanan kesehatan tidak terhalang oleh keadaan ekonomi berkaitan dengan kemampuan memberikan pelayanan kesehatan yang pembiayaannya terjangkau pasien (affordability).

\section{Cat dinding}

Cat dinding menjadi isu strategis menurut pengalaman responden.Berdasarkan hasil analisis penelitian kondisi cat dinding di ruang perawatan rawat inap Puskesmas Pasrepan Kabupaten Pasuruan kurang baik sehingga pasien memiliki pengalaman yang kurang baik terhadap cat dinding. Selain warna kebersihan tembok juga harus diperhatikan, karena akan menjadi pemandangan yang selalu dilihat pasien di ruang perawatan rawat inap. Warna cat dinding yang sudah kusam atau sudah pudar dan mengelupas akan menjadi pemandangan yang tidak indah untuk dilihat.

Menurut Schmitt (1999) salah satu tujuan dari sense strategic objective, yaitu panca indera sebagai pendiferensiasi yang artinya dengan sense marketing untuk 
mendiferensiasikan produk organisasi dengan produk pesaing didalam pasar, memotivasi pelanggan untuk membeli produknya, dan mendistrisbusikan nilai kepada konsumen dan panca indera juga dapat menyediakan nilai yang unik kepada konsumen.

Dan dalam Experiences providers, memperbaiki Product presence yang dalam hal ini adalah melakukan pengecatan ulang dengan warna yang lebih menarikakan dapat memberikan pengalaman yang baik terhadap ruang rawat inap di Puskesmas bagi konsumen.

\section{Kebersihan ruangan perawatan dan kamar mandi}

Kebersihan ruangan perawatan menjadi isu strategis menurut pengalaman responden sedangkan untuk kebersihan kamar mandi menjadi masalah urgent important menurut pengalaman responden.Berdasarkan hasil penelitian dan FGD didapatkan penyebab kurangnya kebersihan kamar mandi dan kebersihan ruangan perawatan yang menyebabkan kurang baiknya pengalaman pelanggan adalah keterbatasan tenaga kebersihan dan petugas tersebut merangkap menjadi penjaga malam jadi kinerjanya kurang optimal, serta budaya pasien kurang menjaga kebersihan.

Kebersihan merupakan hal yang sangat penting dalam industri jasa karena menurut Brown (Wijono, 2007) kebersihan di ruang pemeriksa juga merupakan faktor penting untuk menarik pasien yang dapat menjamin kelangsungan berobat dan meningkatkan cakupan. Dalam Experiences providers, memperbaiki spatial environtment yang dalam hal ini adalah menjaga suasana kebersihan kamar mandi akan dapat memberikan pengalaman pelanggan yang baik terhadap kamr mandi di Puskesmas.

\section{Kelengkapan sarana medis}

Kelengkapan sarana medis menjadi isu strategis menurut pengalaman responden.Kelengkapan sarana medis disini adalah kelengkapan peralatan medis yang ada di Puskesmas Pasrepan Kabupaten Pasuruan. Berdasarkan hasil FGD diketahui pihak Puskesmas sebenarnya sudah mengusulkan ke Dinas Kesehatan Kabupaten Pasuruan tetapi masih dalam proses.

Ketidaklengkapan sarana medis dapat menggangu pelayanan Puskesmas terhadap pasien dan ketidaklengkapan sarana medis dapat mempengaruhi kenyamanan serta kepuasan pasien.menurut Brown (Wijono, 2007) kelengkapan sarana medis termasuk dalam dimensi kenyamanan (amenities), Amenities juga berkaitan dengan penampilan fisik dari fasilitas kesehatan, personil dan peralatan medis maupun non medis. Kelengkapan fasilitas medis merupakan faktor penting untuk menarik pasien yang dapat menjamin kelangsungan berobat dan meningkatkan cakupan. Dalam Experiences providers, memperbaiki Product presence yang dalam hal ini adalah karakteristik produk yaitu melengkapi sarana medis akan dapat memberikan pengalaman pelanggan yang baik.

\section{Kelengkapan sarana non medis}

Kelengkapan sarana non medis menjadi isu strategis menurut pengalaman responden. Kelengkapan sarana non medis di sini adalah kelengkapan sarana di ruang rawat inap yang diantaranya kasur, bantal, sarung bantal, sprei, selimut dewasa, handuk kecil, sprei kecil, selimut bayi, handuk bayi, lap mandi untuk pasien, lemari kecil/bed side cabinet, kursi, tempat sampah plastik untuk pasien dan sikat kuku.

Bila kelengkapan alat dan jumlahnya sudah dipenuhi oleh pihak Puskesmas Pasrepan, maka pasien akan memperoleh pengalaman yang baik terhadap kelengkapan sarana non medis di ruang perawatan rawat inap.

Dari hasil FGD dapat diketahui salah satu penyebab ketidaklengkapan sarana non medis adalah pihak Puskesmas sengaja tidak memberikan perlengkapan sarana untuk pasien karena adanya budaya masyarakat yang mengambil barang-barang yang dipinjamkan oleh Puskesmas.

Menurut Gaspersz (2011) salah satu dimensi atau atribut yang harus diperhatikan dalam kualitas jasa, adalah kelengkapan, menyangkup lingkup pelayanan dan 
ketersediaan sarana pendukung, serta pelayanan komplementer lainnya. Dan dalam Experiences providers melengkapi Product presence yang dalam hal ini adalah karakteristik produk yaitu melengkapi sarana non medis akan dapat memberikan pengalaman pelanggan yang baik.

\section{Makanan pasien}

Makanan pasien menjadi isu strategis menurut pengalaman responden.Makanan pasien adalah makanan yang dipesan oleh Puskesmas Pasrepan Kabupaten Pasuruankepada katering untuk konsumsi makan pasien rawat inap tiga kali sehari.Sakit membuat responden tidak enak atau tidak nafsu untuk makan.Puskesmas Pasrepan Kabupaten Pasuruan tidak memiliki dapur sendiri maka makanan pasien dipesan melalui katering yang ditunjuk.Untuk membuat pasien tertarik kepada makanan yang diberikan dan untuk meningkatkan nafsu makan pasien dapat dilakukan dengan mempercantik tampilan makanan dan menambah variasi menu makanan yang diberikan setiap harinya.Sesuai dengan teori experiential marketing, yaitu dengan mempercantik sense makanan dapat memotivasi pasien untuk mencoba makanan yang diberikan.

\section{C.Relate}

Relate disini adalah niat responden untuk kunjungan ulang dan loyalitas responden terhadap Puskesmas Pasrepan Kabupaten Pasuruan.Relate ini mencakup sense, feel, think dan act. Ini adalah pengalaman individual yang berhubungan dengan orang lain dalam budaya tertentu. Menurut andreani (2007) 'Relate' berkaitan dengan budaya seseorang dan kelompok referensinya yang dapat menciptakan identitas sosial.

Relate pasien rawat inap terhadap Puskesmas Pasrepan Kabupaten Pasuruan melalui niat untuk kunjungan ulang dan advokasi dapat dilihat pada tabel di bawah ini.

Tabel 3 Relate Responden Terhadap Puskesmas Rawat Inap Pasrepan Kabupaten Pasuruan Pertengahan Bulan Mei - Juni Tahun 2013

\begin{tabular}{clcrr}
\hline Indikator & \multicolumn{1}{c}{ Niat } & Rating & Frekuensi & Persentase (\%) \\
\hline \multirow{4}{*}{ Kunjungan ulang } & Tidak berniat & 1 & 1 & 2,9 \\
& Kurang berniat & 2 & 7 & 20,0 \\
& Berniat & 3 & 27 & 77,1 \\
& Sangat berniat & 4 & 0 & 0,0 \\
\hline \multirow{4}{*}{ Advokasi } & Tidak berniat & 1 & 1 & 2,9 \\
& Kurang berniat & 2 & 7 & 20,0 \\
& Berniat & 3 & 27 & 77,1 \\
& Sangat berniat & 4 & 0 & 0,0 \\
\hline
\end{tabular}

Berdasarkan tabel 3dapat diketahui responden yang relate ada 27 responden $(77,1 \%)$, ini artinya sebagian besar pasien berniat untuk memanfaatkan kembali rawat inap di Puskesmas Pasrepan Kabupaten Pasuruan jika memerlukan rawat inap dan akan melakukan advokasi kepada orang lain yang memerlukan pelayanan rawat inap. Tetapi masih ada yang kurang berniat bahkan tidak berniat untuk kunjungan kembali dan melakukan advokasi ke orang lain sebesar ada 8 responden $(22,9 \%)$.

Hal ini menunjukan bahwa pengalaman baik yang dimiliki pelanggan berdasarkan sense, feel, think, dan actakan sangat berpengaruh pada relate. Ini sesuai menurut Kartajaya (2006) konsep eksperiential marketing yang terbagi lima tahapan yaitu sense, feel, think,act dan relate dapat membangun hubungan yang langgeng dengan pelanggan sehingga tercipta loyalitas 
pelanggan. Dan menurut penelitian Nehemia (2010) kelima variabel dalam experiential marketing yaitu sense, feel, think,act dan relate, memiliki pengaruh yang signifikan terhadap loyalitas pelanggan.

Berdasarkan hasil penelitian relate responden dapat dikategorikan Conative loyalty, Conative loyalty adalah responden membuat komitmen untuk menggunakan lagi bila membutuhkan. Bila loyalitas demikian masih berupa pengetahuan dan belum menjadi komitmen (Supriyanto, Ernawaty, 2010).

\section{Pengaruh Sense, Feel, Think, dan Act Terhadap Relate}

Berdasarkan hasil penelitian dapat diketahui bahwa ada kecenderungan pengaruh yang cukup kuat dari sense, feel, think, dan act terhadap niat untuk melakukan kunjungan ulang dan niat untuk merekomendasikan ke orang lain. Dengan memperbaiki sense, feel, think, dan actakan berpengaruh terhadap relate pasien sehingga pasien berniat untuk melakukan kunjungan ulang dan melakukan advokasi kepada orang lain. Hal ini sesuai dengan penelitian Nehemia (2010) kelima variabel dalam experiential marketing yaitu sense, feel, think, act dan relate, memiliki pengaruh yang signifikan terhadap loyalitas pelanggan. Dan menurut Kartajaya (2006) konsep eksperiential marketing yang terbagi lima tahapan yaitu sense, feel, think, act dan relate dapat membangun hubungan yang langgeng dengan pelanggan sehingga tercipta loyalitas pelanggan.

\section{E. Rekomendasi bagi Puskesmas}

Berdasarkan kajian terhadap hasil penelitian dan hasil FGD (Focus Group Discussion) yang sesuai dan bisa diterapkan serta telaah peneliti dapat disusun rekomendasi sebagai berikut:

1. Menata ulang tempat parkir dengan cara:

a. Menambah petugas untuk tempat parkir sehingga kendaraan yang parkir lebih teratur b. Menarik retribusi parkir untuk membuat pasien merasa aman akan kendaraannya

c. Untuk jangka panjang memperluas tempat parkir dengan menjadikan lahan di depan Puskesmas sebagai tempat parkir

d. Untuk jangka panjang direncanakan secara bertahap membangun kanopi untuk keteduhan pasien dan kendaraan pasien

2. Memperbaiki pengalaman kurang baik responden terhadap tarif pelayanan dapat dilakukan dengan cara:

a. Meningkatkan hubungan antar manusia berkaitan dengan interaksi antara petugas kesehatan dan pasien sehingga tercipta pelayanan yang optimal dan memuaskan

b. Petugas kesehatan diharapkan lebih melakukan sosialisasi persyaratan pasien miskin kepada pasien dan keluarganya

c. Menyampaikan informasi tentang jamkesmas melalui rapat lintas sektor seperti rakor kecamatan atau pada mini lokakarya

3. Menyesuaikan standar fisik ruang rawat inap dengan mengusulkan untuk rehab bangunan kepada Dinkes setelah Puskesmas memperbaiki pelayanannya terlebih dahulu

4. Meningkatkan pengalaman yang baik kepada pelanggan terhadap cat dinding di ruang perawatan dapat dilakukan dengan melakukan pengecatan ulang menggunakan warna yang soft dan lebih menarik

5. Puskesmas dapat meningkatkan pengalaman yang baik kepada pelanggan terhadap kebersihan ruang perawatan dan kamar mandi dengan cara:

a. Dilakukan penambahan tenaga kebersihan dengan dilakukan sistem sif

b. Membuat SOP untuk kebersihan (membuat cek list) 
c. Membuat tulisan edukatif tentang kebersihan untuk memberi pelajaran pada pasien

d. Menambah sarana kebersihan seperti tempat sampah

6. Menesuaikan kelengkapan sarana medis dengan standar yang ada dan untuk dapat meningkatkan pengalaman baik pasien dapat dilakukan pengusulan pengadaan alkes ke dinas dengan menggunakan skala prioritas atau untuk alkes yang tidak mahal pihak puskesmas dapat melakukan pengadaan sendiri

7. Menesuaikan kelengkapan sarana non medis dengan standar yang ada dan meningkatkan pengalaman yang baik kepada pelanggan dapat dilakukan dengan cara:

a. Mengusulkan sarana yang dibutuhkan atau belum lengkap ke Dinas Kesehatan

b. Inventarisir daftar sarana non medis yang ada dan jika mau pasien pulang dicek satupersatu

c. Memberi tulisan pada barang inventaris Puskesmas

d. Memberi pengumuman untuk tidak membawa barang Puskesmas dan akan memberikan denda bila barang Puskesmas dibawa pulang

8. Memperbaiki pengalaman kurang baik pelanggan terhadap rasa makanan yang diberikan dapat dilakukan dengan cara meminta kepada pihak katering untuk membuat tampilan makanan lebih menarik dan menambah variasi menu

9. Menyesuaikan kecukupan tenaga dengan standar yang ada dapat dilakukan dengan cara:

a. Melakukan pengusulan tenaga ke Dinas Kesehatan Kabupaten Pasuruan

b. Menggunakan tenaga outsourcing untuk tenaga non kesehatan atau mengoptimalisasi tenaga kesehatan yang ada.

\section{SIMPULAN}

Berdasarkan hasil penelitian dan pembahasan yang telah diuraikan pada bab terdahulu, dapat diambil kesimpulan sebagai berikut:

1. Konsumen pengguna ruang rawat inap di Puskesmas Pasrepan Kabupaten Pasuruan adalah mayoritas responden kelompok umur produktif, memiliki jenis kelamin laki-laki, memiliki pekerjaan sebagai petani, berada pada kelompok tingkat ekonomi rendah, dan pengguna kartu jamkesda atau jamkesmas..

2. Sebagaian besar indikator akses dan proses pelayanan di Puskesmas Pasrepan Kabupaten Pasuruan yang memberikan pengalaman yang baik kepada responden, namun ada beberapa indikator yang memiliki pengalaman yang kurang baik dan menjadi masalah not urgent important anatara lain adalah keteduhan tempat parkir, cat dinding, kebersihan ruang perawatan dan kamar mandi, kelengkapan sarana medis non medis, dan makanan pasien.

3. Sebagian besar pasien cenderung berniat untuk memanfaatkan kembali rawat inap di Puskesmas Pasrepan Kabupaten Pasuruan jika memerlukan rawat inap dan akan melakukan advokasi kepada orang lain yang memerlukan pelayanan rawat inap sebesar $77 \%$.

4. Ada pengaruh dari Sense, feel, think, dan act yang diperoleh responden terhadap relate terhadap ruang rawat inap Puskesmas Pasrepan Kabupaten Pasuruan.

5. Rekomendasi upaya peningkatan loyalitas pelanggan rawat inap Puskesmas Pasrepan Kabupaten Pasuruan berdasarkan experiential marketing:

a. Menata ulang tempat parkir

b. Petugas kesehatan diharapkan lebih melakukan sosialisasi menyampaikan informasi tentang jamkesmas melalui rapat lintas sektor seperti rakor kecamatan atau pada mini lokakarya

c. Menyesuaikan standar fisik ruang rawat inap dengan mengusulkan 
untuk rehab bangunan kepada Dinas Kesehatan Kabupaten Pasuruan

d. Melakukan pengecatan ulang menggunakan warna yang soft dan lebih menarik

e. Melakukan penambahan tenaga kebersihan dengan dilakukan sistem sif dan membuat SOP untuk kebersihan serta menambah sarana kebersihan

f. Melakukan pengusulan pengadaan alkes ke dinas dengan menggunakan skala prioritas

g. Menesuaikan kelengkapan sarana non medis dengan standar yang ada

h. Membuat tampilan makanan lebih menarik dan menambah variasi menu

i. Menyesuaikan kecukupan tenaga dengan standar yang ada dengan melakukan pengusulan tenaga ke Dinas Kesehatan Kabupaten Pasuruan dan mengoptimalisasi tenaga kesehatan yang ada.

\section{DAFTAR PUSAKA}

Andreani, F., (2007). Experiential Marketing (Sebuah Pendekatan Pemasaran). Jurnal Manajemen Pemasaran, Vol. 2, No. 1, http://puslit.petra.ac.id/files/published/jo urnals/MAR/MAR070201/MAR070201 01.pdf (Sitasi 2 Januari 2013).

Dinkes Kab. Pasuruan.,(2009). Laporan Profil Dinas Kesehatan Kabupaten Pasuruan Tahun 2009. Pasuruan: Dinkes Kab. Pasuruan.

Dinkes Kab. Pasuruan.,(2010). Laporan Profil Dinas Kesehatan Kabupaten Pasuruan Tahun 2010. Pasuruan: Dinkes Kab. Pasuruan.

Dinkes Kab. Pasuruan.,(2011). Laporan Profil Dinas Kesehatan Kabupaten Pasuruan Tahun 2011. Pasuruan: Dinkes Kab. Pasuruan.

Gaspersz, V.,(2011). Ekonomi Manajerial. Jakarta: PT. Gramedia Pustaka Utama.
Kartajaya, H.,(2006). Hermawan Kartajaya On Marketing. Jakarta: PT Gramedia Pustaka Utama.

Nehemia.,(2010). Analisis Pengaruh Experiential Marketing Terhadap Loyalitas Pelanggan (Studi kasus : Waroeng Spesial Sambal cab. Sompok Semarang). http://eprints.undip.ac.id/26350/2/JURN AL_ANALISIS_PENGARUH_EXPERI ENTIAL_MARKETING_TERHADAP LOYALITAS_PELANGGAN.pdf (Sitasi 1 Desember 2012).

Pine, B.J., Gilmore, J.H.,(1998). Welcome to the Experience Economy. Harvard Business Review http://rushkolnik.ru/tw files/4995/d4994348/7z-docs/4.pdf (Sitasi 1 Januari 2013).

Rini, E.S.,(2009). Menciptakan Pengalaman Konsumen Dengan Experiential Marketing. Jurnal Manajemen Bisnis, Volume 2, Nomorl, http://repository.usu.ac.id/bitstream/1234 56789/21120/1/jmb-jan20092\%20\%282\%29.pdf (Sitasi 24 November 2012).

Schmitt, B.H., (1999). Experiential Marketing: how to get customers to sense, feel, think, act, and relate to your company and brands. New York: The Free Press.

Supriyanto, S.,(2005). Pemasaran Jasa Industri Kesehatan. Surabaya: Administrasi dan Kebijakan Kesehatan.

Supriyanto, S., Ernawaty.,(2010). Pemasaran Industri Jasa Kesehatan. Yogyakarta: CV Andi Offset.

Supriyanto, S., Wulandari, R.D.,(2007). Manajemen Mutu. Surabaya: Administrasi dan Kebijakan Kesehatan 
Fakultas Kesehatan Masyarakat Wijono, D., (2007). Paradigma dan Universitas Airlangga. Metodologi Penelitian Kesehatan.

Surabaya: Duta Prima Airlangga. 